\title{
Effects of Acute Ammonia Stress on Antioxidant Responses, Histopathology and Ammonia Detoxification Metabolism in Triangle Sail Mussels (Hyriopsis cumingii)
}

\author{
Qianqian Zhao, Ke Feng, Lianbo Zhang, Yunpeng Bai and Weizhi Yao *
}

check for updates

Citation: Zhao, Q.; Feng, K.; Zhang, L.; Bai, Y.; Yao, W. Effects of Acute Ammonia Stress on Antioxidant Responses, Histopathology and Ammonia Detoxification Metabolism in Triangle Sail Mussels (Hyriopsis cumingii). Water 2021, 13, 425. https://doi.org/10.3390/w13040425

Academic Editor: Simone Varandas Received: 21 January 2021

Accepted: 3 February 2021

Published: 5 February 2021

Publisher's Note: MDPI stays neutral with regard to jurisdictional claims in published maps and institutional affiliations.

Copyright: (c) 2021 by the authors. Licensee MDPI, Basel, Switzerland. This article is an open access article distributed under the terms and conditions of the Creative Commons Attribution (CC BY) license (https:/ / creativecommons.org/licenses/by/ $4.0 /)$.

\author{
Laboratory of Freshwater Fish Reproduction and Development (Ministry of Education), \\ Research Center of Fishery Resources and Environment, College of Fisheries, Southwest University, \\ Chongqing 400715, China; zhaoqianqian@email.swu.edu.cn (Q.Z.); fengke127@163.com (K.F.); \\ zhanglianbo@email.swu.edu.cn (L.Z.); b11996697@email.swu.edu.cn (Y.B.) \\ * Correspondence: yaowz@swu.edu.cn; Tel.: +86-23-6825-1070
}

\begin{abstract}
Ammonia is one of the major pollutants in the aquatic ecosystem. Hyriopsis cumingii has great potential for the restoration of eutrophic water. However, there is no study investigating the effect of ammonia exposure in H. cumingii. The median lethal concentration ( $96 \mathrm{~h} \mathrm{LC}_{50}$ ) of unionized ammonium was $12.86 \mathrm{mg} / \mathrm{L}$ in $H$. cumingii. In the study, H. cumingii were exposed to $6.43 \mathrm{mg} \mathrm{L}^{-1}$ unionized ammonium (1/2 $\left.96 \mathrm{~h} \mathrm{LC}_{50}\right)$ for $0,6,12,24,48,72$, and $96 \mathrm{~h}$. High environment ammonia induced antioxidant response to protect the body from oxidative damage. After exposure to ammonia, there was a same trend of induction followed by inhibition of the activities of superoxide dismutase (SOD), catalase (CAT), glutathione peroxidase (GPx), and glutathione-S-transferases (GST) in the hepatopancreas and gills of $H$. cumingii. However, the antioxidant response could not completely counteract the oxidation effect during the exposure period, resulting in lipid peroxidation (LPO) and tissue injury in the hepatopancreas and gills of $H$. cumingii eventually. Moreover, this study indicated that glutamine synthetase (GS), glutamate dehydrogenase (GDH), alanine aminotransaminase (ALT), and aspartate aminotransaminase (AST) in the hepatopancreas and gills may play an important role in ammonia detoxification of $H$. cumingii. Our results will be helpful to understand the mechanism of aquatic toxicology induced by ammonia in shellfish.
\end{abstract}

Keywords: Hyriopsis cumingii; ammonia; oxidative stress; detoxification

\section{Introduction}

Triangle sail mussel (Hyriopsis cumingii) is an important mussel in commercial freshwater pearl culture, which is widely distributed in the rivers and lakes in southern China. The pearls produced by $H$. cumingii are smooth, round in shape, bright in color, rich in protein, and have great cosmetic and medical value [1]. H. cumingii can regulate the phytoplankton community structure and reduce the concentration of nitrogen $(\mathrm{N})$ and Phosphorus $(\mathrm{P})$ by filtering phytoplankton and suspended nutrients [2-4], which plays an important role in enhancing water quality and improving the aquatic environment $[1,3,4]$.

Ammonia is known to be an important toxicant in aquatic environments [5]. Under intensive rearing conditions, high stocking density and excessive feeding lead to an increase in nitrogenous load such as uneaten food, animal excretion, and corpses of animals and plants in the aquaculture water [6,7]. Ammonia can easily be accumulated to high concentrations due to the ammonification of these nitrogenous organics [8,9]. Besides, ammonia can enter the water environment from sewage effluents, decomposition of biologic wastes, and industrial and agricultural wastes [9]. The term ammonia is present as two chemical forms, ionized ammonium $\left(\mathrm{NH}_{4}{ }^{+}\right)$and unionized ammonium $\left(\mathrm{NH}_{3}\right)$, which are in equilibrium in aqueous environments. $\mathrm{NH}_{3}$ is considerably more toxic than $\mathrm{NH}_{4}{ }^{+}$ because it can readily spread across the gill membranes due to the lipid solubility and 
nonpolarity. The $\mathrm{NH}_{3}-\mathrm{NH}_{4}{ }^{+}$ratio mainly depends on $\mathrm{pH}$ and temperature [10]. Under adverse water environment, ammonia toxicity becomes a major issue, which leads to oxidative stress [11,12], immune suppression [8,13], tissue erosion and degeneration [5,14], growth reduction [15,16], and high mortality [7].

When exposed to environmental stressors, the bivalves will produce a lot of reactive oxygen species (ROS). To neutralize the oxidative effect of generated ROS, organisms employ antioxidant defense system to counteract oxidative stress and prevent oxidant damage [17]. If the antioxidant response is insufficient to clear excessive level of stressinduced ROS, it will cause cellular damage, such as lipid peroxidation (LPO), tissue injury and DNA fragmentation $[14,18,19]$. There are numerous studies about antioxidant response in fish concerning acute and chronic ammonia toxicity [20-22]. Some studies have also reported the antioxidant response of shellfish after exposure to phycotoxin [18] and heavy metals [23]. However, studies of the effects of ammonia exposure are relatively scarce in shellfish.

Ammonia is also the nitrogen end product of protein and amino acid metabolism, which is excreted into the surrounding environment across the gills in teleosts $[6,15]$. However, under certain circumstances such as high environment ammonia (HEA), aquatic animals are confronted simultaneously with the accumulation of endogenous ammonia and uptake of exogenous ammonia, which will result in the inhibition of ammonia excretion [24]. There are many mechanisms to cope with high internal ammonia in adverse environments, such as the synthesis of less-toxic glutamine and urea [25]. Previous studies suggested that glutamine synthesis was an effective ammonia detoxification strategy in fish, such as Oncorhynchus mykiss [25] and Paramisgurnus dabryanus [6,24]. At present, the study of ammonia on freshwater mussels was mainly focused on toxicity assessment, filtration behavior, hemocyte status, DNA damage and apoptosis, cellular energy allocation, and so on [26-29]. However, the research about the mechanism of ammonia toxicity in bivalves is still limited. Additionally, it remains unknown whether $H$. cumingii could detoxify ammonia into glutamine under ammonia stress.

This study aimed to evaluate the effects of ammonia exposure on the behavior, ammonia accumulation, antioxidant response, partial amino acid metabolism, glutamine synthesis, and histopathological alterations in H. cumingii. The results are useful for understanding the dynamic response model of shellfish to ammonia toxicity and provide a reference for the healthy and sustainable development of H. cumingii.

\section{Materials and Methods}

\subsection{Experimental Mussel and Chemicals}

H. cumingii (shell length $77.69 \pm 0.22 \mathrm{~mm}$, wet weight: $45.44 \pm 0.26 \mathrm{~g}$ ), aging one and a half years old, were obtained from Zhejiang Province during the summer of 2019. Individuals without shell damage were acclimatized to laboratory conditions for a week in plastic boxes ( $440 \mathrm{~mm}$ length $\times 330 \mathrm{~mm}$ width $\times 210 \mathrm{~mm}$ height) containing chlorine-free water by constant artificial aeration for $48 \mathrm{~h}$.

The water was aerated continuously during the rearing period. Dissolved oxygen (DO), water temperature and $\mathrm{pH}$ were measured daily at $8.05-9.05 \mathrm{mg} / \mathrm{L}, 23.8-24.6^{\circ} \mathrm{C}$ and 7.40-7.75, respectively. Half of the rearing water was exchanged daily.

$\mathrm{NH}_{4} \mathrm{Cl}$ (analytically pure) was purchased from the Kelong Chemical Co., Ltd. (Chengdu, China). A stock solution of high purity $\mathrm{NH}_{4} \mathrm{Cl}\left(10 \mathrm{~g} \mathrm{~L}^{-1}\right)$ was prepared for the source of total ammonia-nitrogen (TAN), which was subsequently diluted to the desired concentrations.

\subsection{Acute Toxicity Test}

The acute toxicity test was conducted by the static renewal method. Based on the pre-experiment, eight treatments and one control group were set up according to the equal logarithmic distance (Table 1). Mussels were randomly distributed into 27 tanks (20 L) with 10 mussels per tank in triplicate. The $\mathrm{DO}$ and water temperature were maintained to be no less than $5.0 \mathrm{mg} / \mathrm{L}$ and $25.20 \pm 0.25^{\circ} \mathrm{C}$, respectively. The $\mathrm{pH}$ was adjusted to $7.70 \pm 0.1$ 
using $\mathrm{NaOH}$ solution $\left(1 \mathrm{~mol} \mathrm{~L}^{-1}\right)$ and $\mathrm{HCl}\left(1 \mathrm{~mol} \mathrm{~L}^{-1}\right)$. Previous studies have shown no significant effect on the toxicity of ammonia in mussels with or without the presence of a substrate $[30,31]$. When the shell-valves opened and showed no response after being stimulated by a glass rod, or the ax-foot stretched abnormally and did not contract after being stimulated, the mussel can be judged as dead. Mortality was checked at $24 \mathrm{~h}$ intervals during $96 \mathrm{~h}$. The dead mussels were removed from the containers and each test solution was renewed every $24 \mathrm{~h}$.

Table 1. The mortality of the acute toxicity test of unionized ammonium in Hyriopsi cumingii.

\begin{tabular}{cccccc}
\hline \multirow{2}{*}{ Exposure Concentration (mg/L) } & Mussels (unit) & \multicolumn{4}{c}{ Exposure Time (h) } \\
\cline { 3 - 6 } & & $\mathbf{2 4}$ & $\mathbf{4 8}$ & $\mathbf{7 2}$ & $\mathbf{9 6}$ \\
\hline 0.00 & 30 & $0 \%$ & $0.00 \%$ & $0.00 \%$ & $0.00 \%$ \\
$3.96 \pm 0.09$ & 30 & $0 \%$ & $0.00 \%$ & $3.33 \%$ & $13.33 \%$ \\
$5.46 \pm 0.16$ & 30 & $0 \%$ & $6.67 \%$ & $10 \%$ & $16.67 \%$ \\
$7.53 \pm 0.08$ & 30 & $0 \%$ & $3.33 \%$ & $10 \%$ & $16.67 \%$ \\
$10.39 \pm 0.98$ & 30 & $0 \%$ & $6.67 \%$ & $13.30 \%$ & $26.67 \%$ \\
$14.33 \pm 0.25$ & 30 & $0 \%$ & $16.67 \%$ & $33.30 \%$ & $63.33 \%$ \\
$19.78 \pm 0.33$ & 30 & $0 \%$ & $23.33 \%$ & $33.30 \%$ & $73.33 \%$ \\
$27.29 \pm 0.15$ & 30 & $3.33 \%$ & $33.33 \%$ & $46.67 \%$ & $100 \%$ \\
$37.65 \pm 0.20$ & 30 & $3.33 \%$ & $20.00 \%$ & $56.67 \%$ & $100 \%$ \\
\hline
\end{tabular}

The exposure concentrations are presented as mean \pm standard error (SE).

\subsection{Ammonia Challenge Test}

According to the results of the acute toxicity test of ammonia, H. cumingii were exposed to $6.43 \mathrm{mg} \mathrm{L}^{-1}$ unionized ammonium $\left(1 / 296 \mathrm{~h} \mathrm{LC}_{50}\right)$ with the volume of $20 \mathrm{~L}$. Nine mussels ( 3 mussels $\times 3$ replicates) were dissected at 0 (control), 6, 12, 24, 48, 72, and $96 \mathrm{~h}$ of exposure. Each time point had three repeated tanks. The full water was renewed every $12 \mathrm{~h}$ by replacing the medium with a fresh $\mathrm{NH}_{4} \mathrm{Cl}$ solution. Mussels were not fed during the experiment.

\subsubsection{Sampling and Biochemical Analysis}

Hemolymph samples were extracted from the adductor muscle sinus by inserting a $1 \mathrm{~mL}$ sterilized syringe (needle gauge: $0.45 \times 16 \mathrm{RWLB}$ ). For each replicate, three mussels were sampled and pooled to obtain sufficient hemolymph and reduce individual differences. Three replicates were prepared for each treatment. Hemolymph samples were centrifuged at $3500 \times \mathrm{g}$ for $10 \mathrm{~min}$ at $4{ }^{\circ} \mathrm{C}$. After the hemolymph was collected, the hepatopancreas and gills of the mussels were sampled. The tissue was homogenized with nine volumes of ice-cold normal saline and centrifuged at $3500 \mathrm{rpm}$ for $20 \mathrm{~min}$ at $4{ }^{\circ} \mathrm{C}$. The supernatant was collected and stored at $-80^{\circ} \mathrm{C}$ until further analysis. All subsequent determinations were performed in duplicate.

The activities of alanine aminotransaminase (ALT), aspartate aminotransaminase (AST), alkaline phosphatase (AKP) and the ammonia content in the hemolymph, the activities of superoxide dismutase (SOD), catalase (CAT), glutathione peroxidase (GPx), glutathione-S-transferases (GST), glutamine synthetase (GS), and glutamate dehydrogenase (GDH) as well as the content of glutathione (GSH) and malondialdehyde (MDA) in the hepatopancreas and gills were measured in the present study. Total protein (TP), SOD, CAT, MDA, GS, and GDH were measured using commercial kits which were purchased from Shanghai Optimal Biotechnology Company (Shanghai, China). The kits for alkaline phosphatases (AKP), ALT, AST, GPx GST, GSH, and the ammonia content were the products of Nanjing Jiancheng Bioengineering Institute (Nanjing, China). All the measurements were conducted according to manufacturer's instructions. 


\subsubsection{Histological Examination}

The hepatopancreas and gills were sampled at $0,24,48$, and $96 \mathrm{~h}$ under $6.43 \mathrm{mg} \mathrm{L}^{-1}$ unionized ammonium for histopathological analysis. The tissues from each mussel were individually fixed in $4 \%$ paraformaldehyde for $24 \mathrm{~h}$. The samples were cut into slices of $5 \mu \mathrm{m}$ thick following by ethanol dehydration and paraffin embedding, and then stained with hematoxylin and eosin (HE). Finally, pathological observations were performed under a panoramic scanner (P250, 3D Histech, Hungary).

\subsection{Statistical Analysis}

In this research, SPSS 23.0 software (IBM, Chicago, IL, USA) was used for all statistical analyses. All data for the tested parameters were presented as mean \pm standard error (SE). After testing data normality and variance homogeneity, statistical difference was determined by one-way analysis of variance (ANOVA) followed by Duncan's multiple rang test. Significant differences were considered at $p<0.05$. The data were graphed using Origin 2019 (OriginLab Corp., Northampton, MA, USA).

\section{Results}

\subsection{Physiological Changes of H. cumingii under Ammonia Stress}

The physiological changes of $H$. cumingii within the first day of ammonia exposure were observed continuously. In the first $1 \mathrm{~h}$, a large number of mussels stretched out their foot and quickly retracted when touched. After $3 \mathrm{~h}$ of exposure, the retraction speed of foot became slower after touching, the ability to close shells became weak, and the body fluid outflowed. After $8 \mathrm{~h}$ of exposure, the shell-valves were closed and no foot flowed out. With the increase of exposure time, the foot rarely stretched, water spraying was weak, and then the adductor muscle of poisoned mussels was paralyzed and foot flowed out.

\subsection{The $96 \mathrm{~h} \mathrm{LC}_{50}$ of $\mathrm{NH}_{4} \mathrm{Cl}$ Exposure}

No mussel died in the control group during the 96-h test period. Mortality increased with the increase of unionized ammonium concentration (Table 1). After $24 \mathrm{~h}$ of exposure, H. cumingii only died in 27.29 and $37.65 \mathrm{mg} / \mathrm{L}$ groups. After $48 \mathrm{~h}$ of exposure, the mortality was lower than $50 \%$ in all concentrations. After $72 \mathrm{~h}$ of exposure, the mortality was more than $50 \%$ only in the highest concentration. After $96 \mathrm{~h}$ of exposure, all mussels died in 27.29 and $37.65 \mathrm{mg} / \mathrm{L}$ groups. Using the linear interpolation method, the $96 \mathrm{~h} \mathrm{LC}_{50}$ for unionized ammonium was $12.86 \mathrm{mg} / \mathrm{L}$ in $\mathrm{H}$. cumingii.

\subsection{Effects of Biochemical Parameters in the Hemolymph}

After $6 \mathrm{~h}$ of exposure, ammonia content in the hemolymph of H. cumingii had a sharp increase $(p<0.05)$, and maintained in high levels with the extension of exposure time (Figure 1A). The highest value was obtained at $96 \mathrm{~h}$, which increased to 262.02-fold of the control $(p<0.05)$. The activities of AKP, ALT and AST in the hemolymph showed the same trend of induction followed by inhibition. Compared with the control, all of them were significantly elevated after $6 \mathrm{~h}$ of exposure. The activity of AKP reached a peak $(p<0.05)$ at $24 \mathrm{~h}$ and decreased to normal level at $96 \mathrm{~h}$ (Figure 1B). The activity of ALT (Figure 1C) and AST (Figure 1D) reached their maximum value $(p<0.05)$ in response to $72 \mathrm{~h}$ of ammonia exposure and were significantly higher than that of the control during the exposure period. 

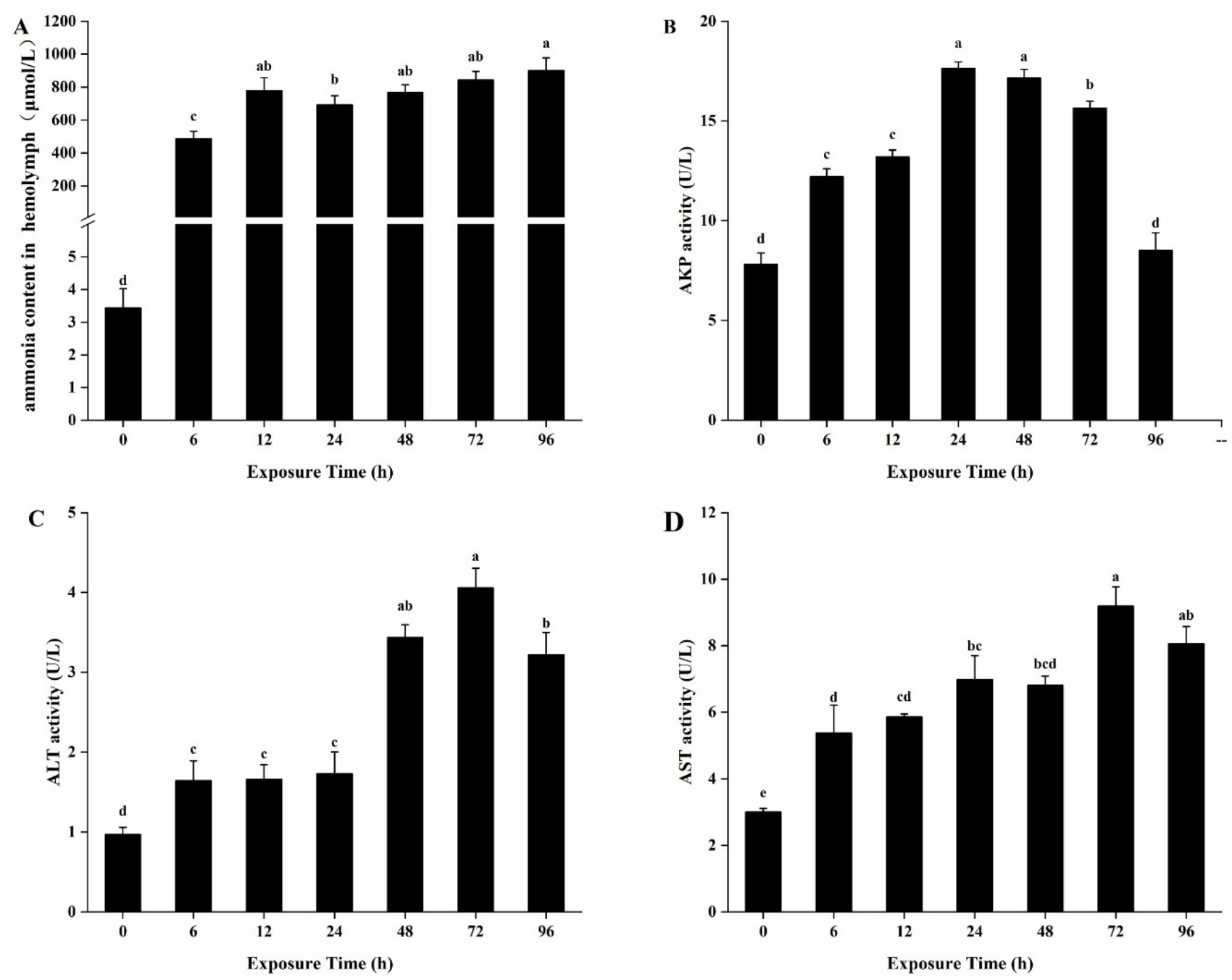

Figure 1. The contents of ammonia in the hemolymph (A), and the activities of AKP (B), ALT (C), and AST (D) in the hemolymph of $H$. cumingii exposed to $6.43 \mathrm{mg} \mathrm{L}^{-1}$ unionized ammonium for 0 (control), 6, 12, 24, 48, 72, and $96 \mathrm{~h}$. Values are presented as the mean $\pm \mathrm{SE}(n=6)$. Superscripted lowercase letters indicate a significant effect of exposure time $(p<0.05)$.

\subsection{Antioxidant Enzymes Activities and Contents of GSH and MDA in the Hepatopancreas}

Antioxidant enzymes of the hepatic tissues are illustrated in Figure 2. The activities of SOD, CAT and GPx showed a trend of induction followed by inhibition in the hepatopancreas. The activity of SOD was significantly upregulated at $6 \mathrm{~h}$ and increased to the highest value at $12 \mathrm{~h}$. After $48 \mathrm{~h}$ of exposure, the activity of SOD decreased to the normal level $(p>0.05)$ (Figure 2A). The CAT activity of the hepatopancreas was significantly higher than that of the control from 48 to $96 \mathrm{~h}$ (Figure 2B). The activity of GPx was significantly enhanced after $12 \mathrm{~h}$ of exposure and then peaked at $72 \mathrm{~h}$ (Figure 2C). GST showed an upward trend and was significantly upregulated at $48 \mathrm{~h}$ and continued to increase until the end of the exposure (Figure 2D).

The GSH contents in the hepatopancreas reached peak at $48 \mathrm{~h}$, which was 1.53-fold of the control $(p<0.05)$ (Figure 2E). The content of MDA in the hepatopancreas also presented an upward trend, which was significantly upregulated $(1.42$-fold, $p<0.05)$ at $48 \mathrm{~h}$ (Figure 2F). 

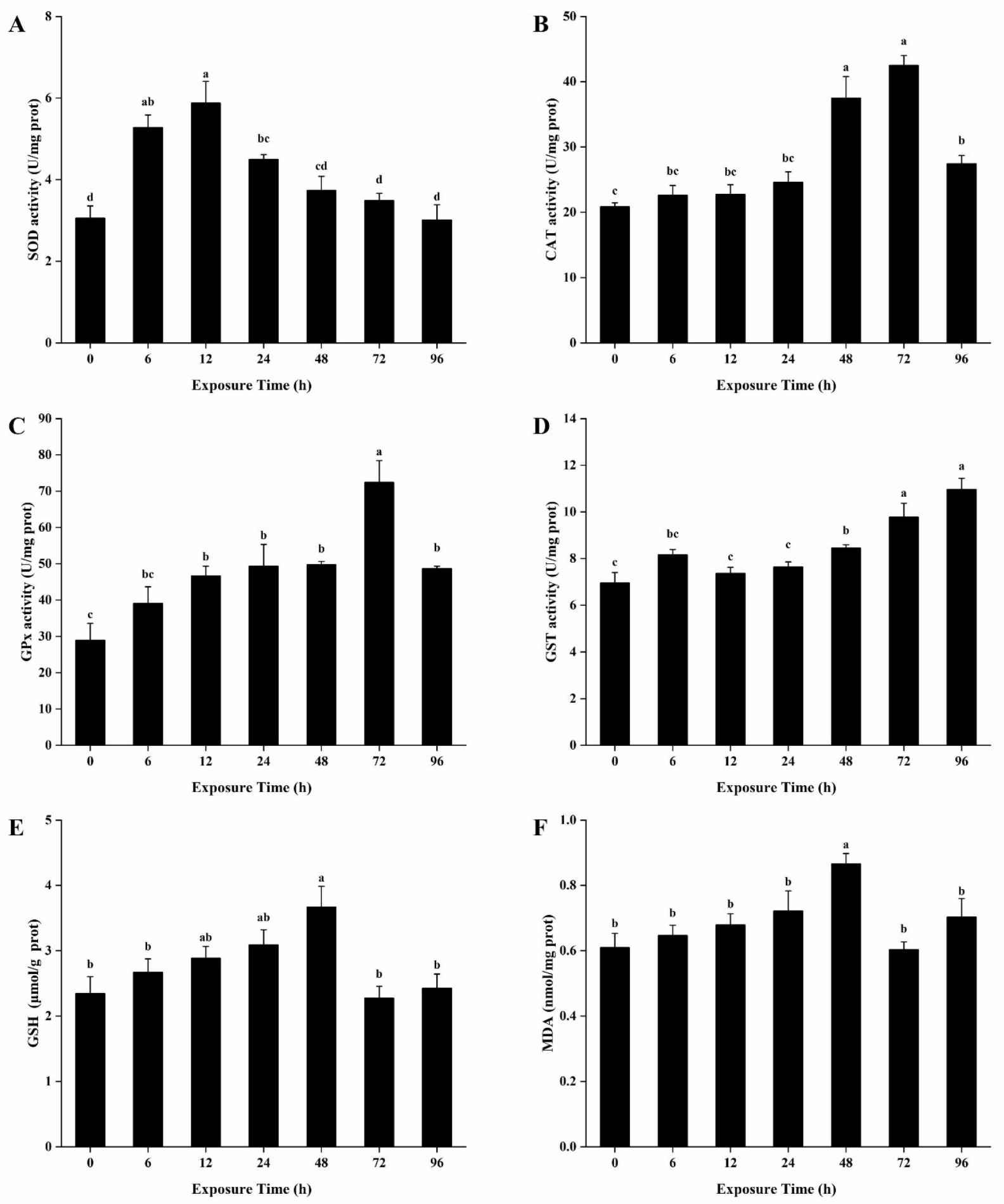

Figure 2. The activities of SOD (A), CAT (B), GPx (C), and GST (D) and the contents of GSH (E), MDA (F) in the hepatopancreas of $H$. cumingii exposed to $6.43 \mathrm{mg} \mathrm{L}^{-1}$ unionized ammonium for 0 (control), 6, 12, 24, 48, 72, and $96 \mathrm{~h}$. Values are presented as the mean $\pm \mathrm{SE}(n=6)$. Superscripted lowercase letters indicate a significant effect of exposure time $(p<0.05)$.

\subsection{Antioxidant Enzymes Activities and Contents of GSH and MDA in the Gills}

Ammonia exposure had a clear time effect on antioxidant enzyme activities and contents of GSH and MDA in the gills of H. cumingii (Figure 3). The activity of SOD was significantly increased at $48 \mathrm{~h}$ and reached the highest value at $96 \mathrm{~h}$, which was 1.71 -fold of the control $(p<0.05)$ (Figure 3A). The activities of CAT, GPx and GST in the gills of 
H. cumingii showed a same trend of induction followed by inhibition. The highest levels of the three enzymes were obtained at 48,72 , and $72 \mathrm{~h}$, and the peak was 1.44-fold, 2.45-fold, and 1.36-fold of the controls $(p<0.05)$, respectively (Figure 3B-D).
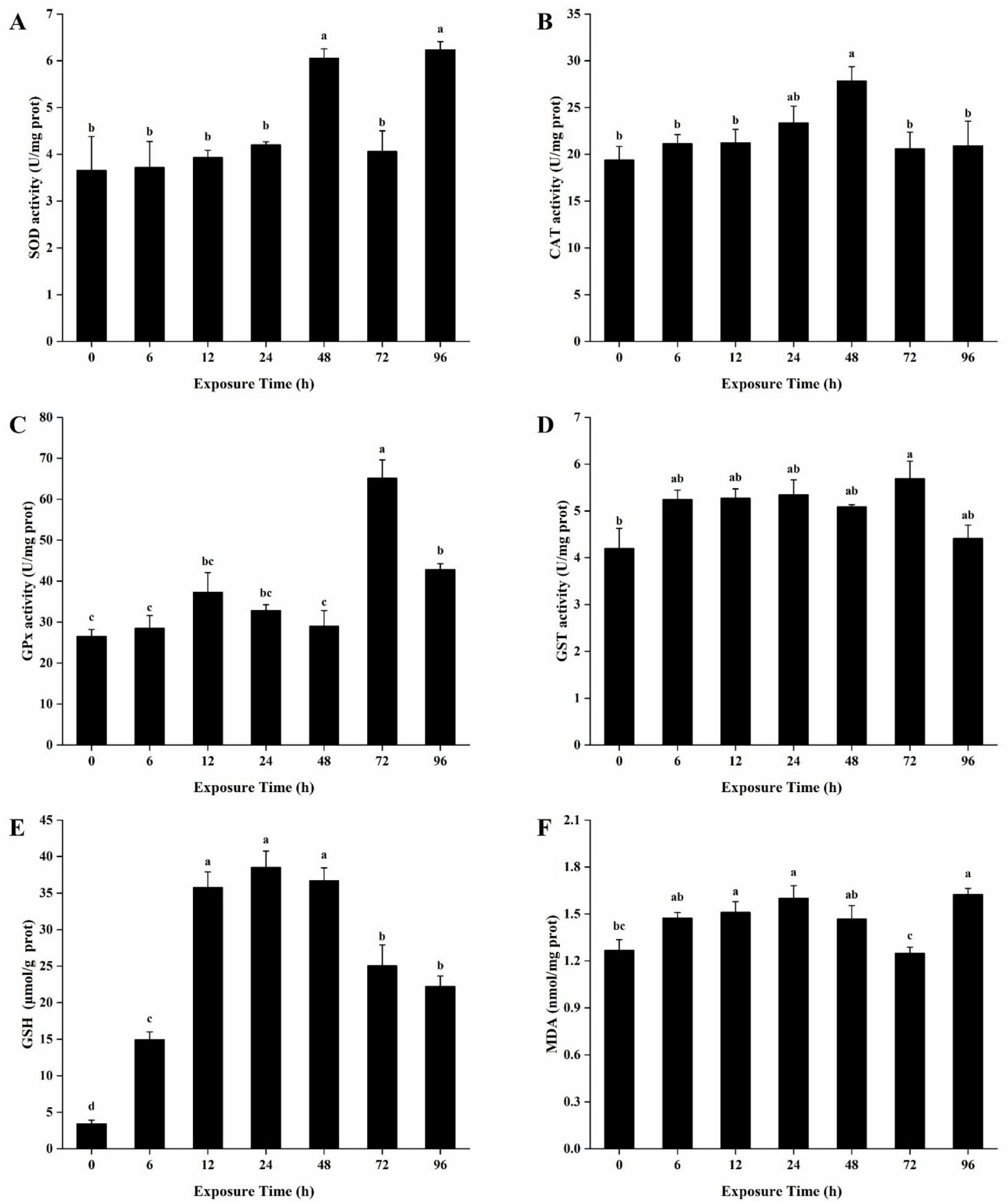

Figure 3. The activities of SOD (A), CAT (B), Gpx (C), and GST(D) and the contents of GSH (E), MDA (F) in the gills of H. cumingii exposed to $6.43 \mathrm{mg} \mathrm{L}^{-1}$ unionized ammonium for 0 (control), 6, 12, 24, 48, 72, and $96 \mathrm{~h}$. Values are presented as the mean \pm SE $(n=6)$. Superscripted lowercase letters indicate a significant effect of exposure time $(p<0.05)$. 
The GSH content was significantly higher than that of the control during all the exposure periods (Figure 3E). The content of GSH was significantly upregulated after $6 \mathrm{~h}$ of exposure, and then began to decline after reaching the peak $(11.28$-fold, $p<0.05)$ at $24 \mathrm{~h}$. Significant increase in the gills for MDA was evident at $24 \mathrm{~h}$, and finally reached the highest value $(1.28$-fold, $p<0.05)$ at $96 \mathrm{~h}$ (Figure $3 \mathrm{~F})$.

\subsection{Histopathological Observations}

Pathological alterations were not observed in control mussels (Figure 4A). The lumen boundary of the digestive tubule is obvious. From 24 (Figure 4B) to $96 \mathrm{~h}$, slight to severe hemolytic infiltration, aggregation of lipofuscin, atrophy of digestive cells, and exfoliation of epithelial cells occurred. After $48 \mathrm{~h}$, the lumen became smaller (Figure 4C). After $96 \mathrm{~h}$, a large area necrosis of epithelial cells and severe degeneration of digestive tubules were observed. Furthermore, the lumen basically disappeared parallel with vacuolation occurring (Figure 4D).

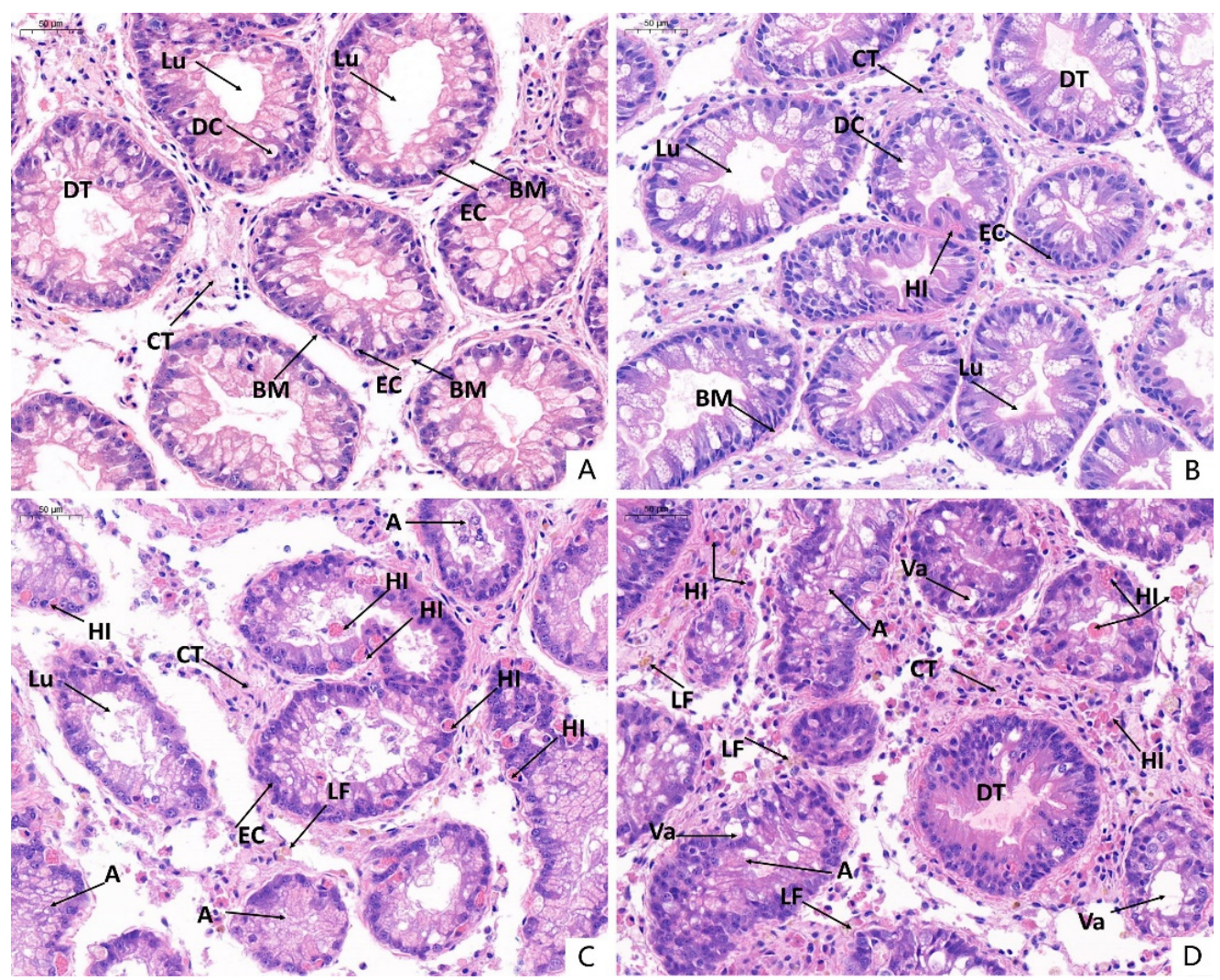

Figure 4. Time-course histopathological changes in hepatopancreas of $H$. cumingii under ammonia stress. (A) Control hepatopancreas; (B-D). Hepatopancreas at hours 24, 48, and 96, respectively. DT: digestive tubules; DC: digestive cell; CT: connective tissue; Lu: lumen; EC: epithelial cell; BM: basement membrane; LF: lipofuscin; HI: hemolytic infiltration; Va: vacuole; A: atrophy. Scale bar $=50 \mu \mathrm{m}(\times 200)$.

The gills of control are shown in Figure 5A. The gill filaments were arranged densely and structure integrally and the epithelial columnar cells of filaments were arranged in line. After $24 \mathrm{~h}$ of exposure, a small amount of lipofuscin in the lumen of gill filaments was observed with mild cilia exfoliated (Figure 5B). After 48 h, further cilia exfoliation and lipofuscin aggregation were observed, interlamellar space increased, and connective tissue atrophied slightly (Figure 5C). At $96 \mathrm{~h}$, the ciliary structure was almost lost completely, pyknosis occurred in the nucleus of columnar cells, and the connective tissue on the inside of columnar cells atrophied and disappeared (Figure 5D). 

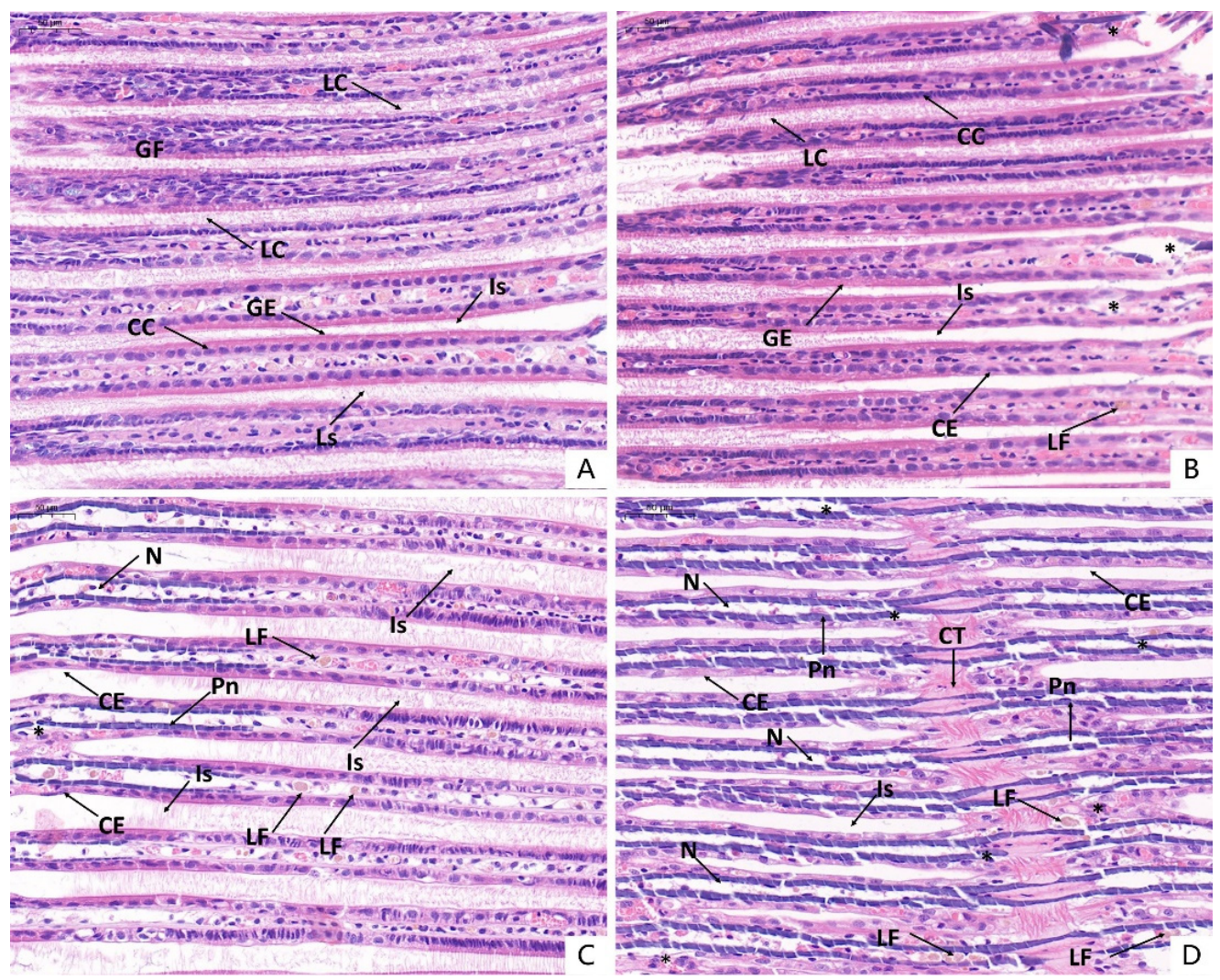

Figure 5. Time-course histopathological changes in gills of $H$. cumingii under ammonia stress. (A) Control gills; (B-D) Gills at hours 24, 48, and 96, respectively. LC: lateral cilia; GF: gill filament; GE: gill epithelium; CC: columnar cell; Is, inter-lamellar space; CT: connective tissue; LF: lipofuscin; Pn: pyknosis of nuclear; N: necrosis; CE: cilia exfoliation; asterisks: loss of structural integrity. Scale bar $=50 \mu \mathrm{m}(\times 200)$.

\subsection{Activities of Enzymes Related to Ammonia Detoxification Metabolism in the Hepatopancreas}

The activities of GS, GDH, ALT, and AST in the hepatopancreas of H. cumingii exposed to ammonia showed a same trend of induction followed by inhibition (Figure 6). The activity of GS increased significantly after $6 \mathrm{~h}$ of exposure and reached a peak (1.23-fold, $p<0.05$ ) at $12 \mathrm{~h}$ (Figure 6A). The activity of GDH increased significantly at $12 \mathrm{~h}$, and decreased after reaching the maximum at $48 \mathrm{~h}$ (Figure 6B). The activity of ALT at 12 and $24 \mathrm{~h}$ were significantly higher than those of other time points (Figure 6C). The activity of AST increased significantly after $6 \mathrm{~h}$ of exposure except that at $24 \mathrm{~h}$, and reached the inflection point at $72 \mathrm{~h}$ (Figure 6D). 

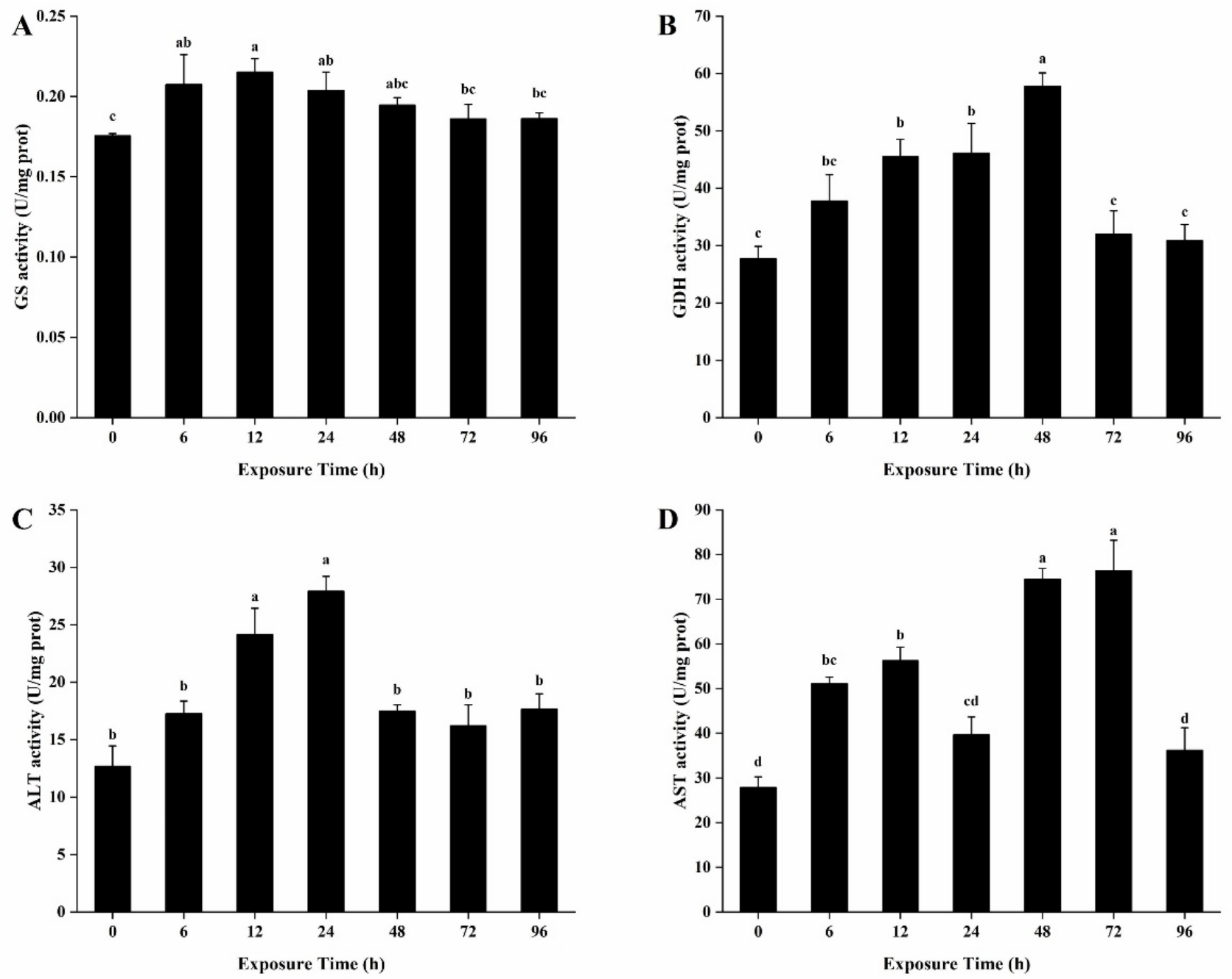

Figure 6. The activities of GS (A), GDH (B), ALT (C), and AST (D) in the hepatopancreas of H. cumingii exposed to $6.43 \mathrm{mg} \mathrm{L}^{-1}$ unionized ammonium for 0 (control), 6, 12, 24, 48, 72, and $96 \mathrm{~h}$. Values are presented as the mean $\pm \mathrm{SE}(n=6)$. Superscripted lowercase letters indicate a significant effect of exposure time $(p<0.05)$.

\subsection{Activities of Enzymes Related to Ammonia Detoxification Metabolism in the Gills}

Exposed to $\mathrm{NH}_{4} \mathrm{Cl}$ had little effect on GS activity in the gills, which only increased significantly at $72 \mathrm{~h}$ (Figure 7A). The activity of GDH increased significantly after $12 \mathrm{~h}$ of exposure and reached the maximum value $(1.76$-fold, $p<0.05)$ at $72 \mathrm{~h}$ (Figure $7 \mathrm{~B})$. The activities of ALT and AST showed a trend of increase. The activities of ALT and AST increased significantly after 6 and $24 \mathrm{~h}$ of exposure, respectively (Figure 7C,D). 

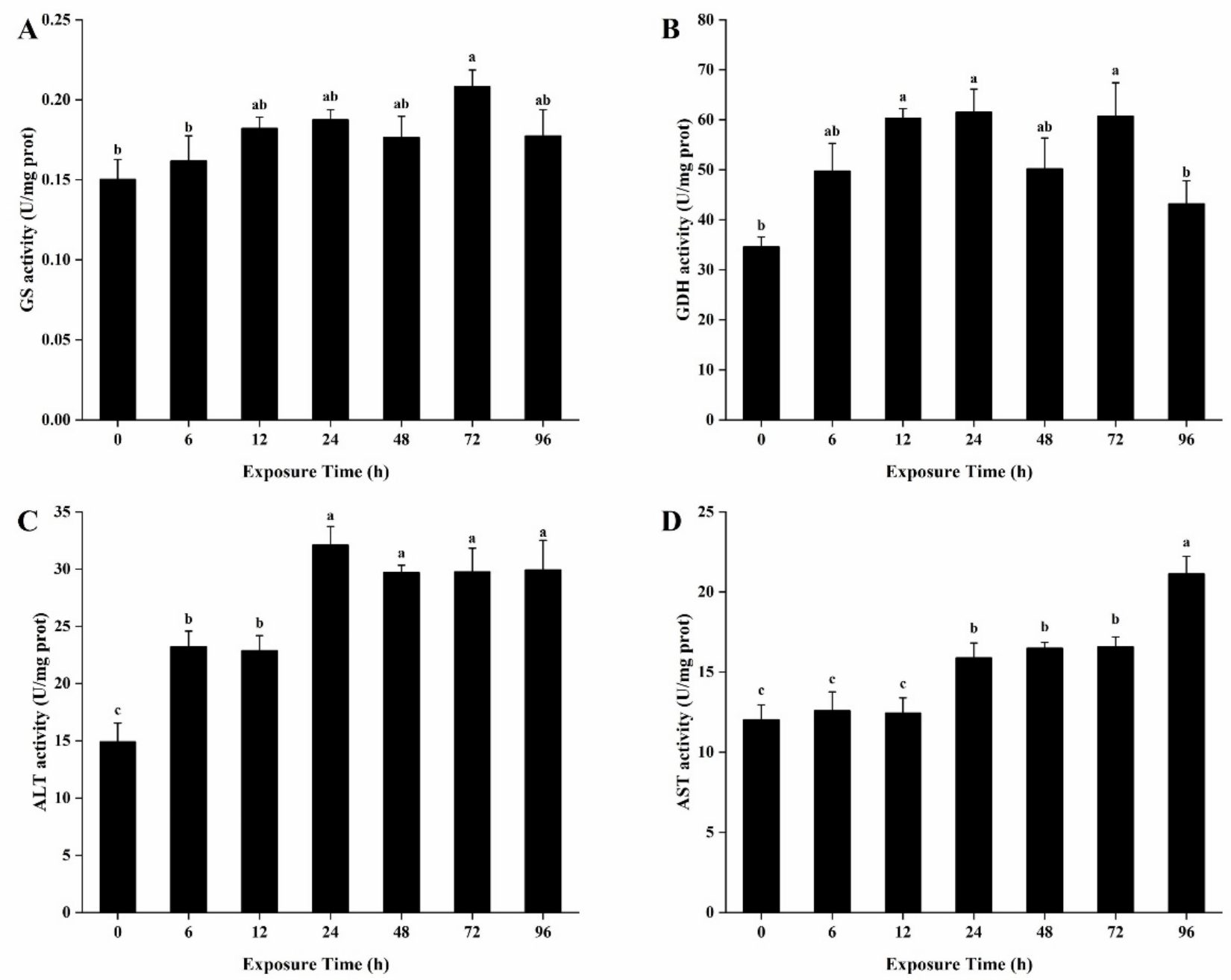

Figure 7. The activities of GS (A), GDH (B), ALT (C), and AST (D) in the gills of H. cumingii exposed to $6.43 \mathrm{mg} \mathrm{L}^{-1}$ unionized ammonium for 0 (control), $6,12,24,48,72$, and $96 \mathrm{~h}$. Values are presented as the mean \pm SE $(n=6)$. Superscripted lowercase letters indicate a significant effect of exposure time $(p<0.05)$.

\section{Discussion}

In the present study, the $96 \mathrm{~h} \mathrm{LC}_{50}$ of unionized ammonium was $12.86 \mathrm{mg} / \mathrm{L}$ in H. cumingii, which is higher than those of most fish and shellfish, such as three cyprinid fish [32], Corbicula fluminea [29], Pseudunio auricularius [26] and Villosa iris glochidia [33]. Moreover, when the concentration of ammonia reached a high level in the environment, the excretion of ammonia was inhibited, and the influx of exogenous ammonia was stimulated, resulting in the increase of ammonia in the body $[34,35]$. The ammonia concentration in the hemolymph reached 262.02-fold of the control after $96 \mathrm{~h}$ of exposure in our research. The capacity for the accumulation of ammonia in H. cumingii was much higher than those in many other fishes, such as P. dabryanus [6] and Eriocheir sinensis [36]. The results revealed that $H$. cumingii has a strong tolerance to ammonia.

In general, AKP, ALT and AST are used as indicators of tissue damage caused by environmental pollutants [37]. AKP is a key enzyme in cellular homeostasis, which is involved in signal transduction, physiological metabolism and environmental adaptation [38,39]. In the present study, the activity of AKP showed a trend of induction before inhibition. Previous studies showed the activity of AKP increased in Cyprinus carpio by exposing

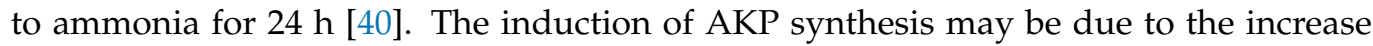
of membrane permeability to meet the need of cell metabolism [38]. Additionally, the subsequent inhibition may be ascribed to the cell damage [40]. Hemolymph transaminases 
are also used as indicators of hepatopancreas damage after stress [41]. In this experiment, the activity of ALT and AST increased at first and then decreased. In previous research, exposure of ammonia also stimulated the increase of ALT and AST in Paramisgurnus dabryanus and Cyprinus carpio [6,42]. Elevated levels of ALT and AST in hemolymph indicated that ammonia led to cell damage and leakage in hepatopancreas [37].

Oxidative stress is defined as an imbalanced state between oxidants and antioxidants, which damages macromolecules such as DNA, lipids and proteins, and disrupts cell metabolism and regulation [19]. Under normal conditions, generation and clearance of ROS maintain a dynamic balance of the antioxidant system, while oxidative stress will generate many ROS under adverse conditions in the organism [11]. Excess ROS would destroy cell membranes, form lipid peroxides and oxidized proteins, and inhibit the detoxification of the body [43,44].

The antioxidant system is composed of antioxidant enzymes (such as SOD, CAT and GPx) and antioxidants (such as GSH), which has a strong detoxification effect on harmful ROS. SOD is the first and most important line of defense in the antioxidant system [45]. SOD can catalyze the disproportionation of superoxide anion radicals to produce oxygen and hydrogen peroxide, reducing or eliminating the damage of ROS to the cytoplasmic membrane. In this study, the SOD activities in the hepatopancreas were upregulated and reached a higher peak earlier than those in gills, indicating that hepatopancreas was more sensitive to acute ammonia exposure in H. cumingii. CAT and GPx participate in the conversion of $\mathrm{H}_{2} \mathrm{O}_{2}$ into $\mathrm{O}_{2}$ and $\mathrm{H}_{2} \mathrm{O}$, which reduces reactive oxygen free radicals and maintains cell dynamic balance in organisms [46-48]. In previous study, the CAT and GPx activities showed a trend of upregulation and then downregulation after exposure of cadmium in the liver and kidney of Oreochromis mossambicus [43]. The time of significant upregulation of GPx (12 h) was earlier than that of CAT ( $48 \mathrm{~h})$, suggesting that GPx reflected faster than CAT in the conversion of $\mathrm{H}_{2} \mathrm{O}_{2}$ in the hepatopancreas in H. cumingii.

GSH is the most abundant intracellular low molecular weight antioxidant in the antioxidant system. GSH can directly scavenge singlet oxygen and hydroxyl radicals to intact cells under oxidative stress, and is used as a cofactor for the biotransformation enzymes GST and the antioxidative enzyme GPx [49,50]. In our study, the GSH increased much more in gills than that in hepatopancreas, which may be because the consumption of GSH as a substrate is almost the same as that induced by oxidative stress in hepatopancreas. This is consistent with the previous studies that glutathione depletion limited the ability to detoxify or prevent oxidative damage in organisms [51]. GST belongs to the family of multifunctional proteins, which plays a key role in the detoxification of organisms under the stress of harmful xenobiotic and endobiotic compounds [50]. In this study, the activity of GST was upregulated significantly from $48 \mathrm{~h}$ until the end of the experiment in hepatopancreas, while was only upregulated significantly at $72 \mathrm{~h}$ in gills. It suggested that hepatopancreas may be the main site, where it can produce more soluble GST to detoxify and protect cells from oxidative damage. This result is in agreement with previous studies on the effect of ambient ammonia in Lamellidens marginalis [52].

MDA is the final product of LPO and plays a major role in the loss of cell function caused by oxidative stress conditions [53]. At the initial stage of ammonia stress, MDA content showed no significant difference, indicating that the antioxidant defense system played a role in effectively scavenging the excess active radical balance in $\mathrm{H}$. cumingii. With the time elapsed, the contents of MDA in hepatopancreas and gills were upregulated significantly. The phenomenon implied that although ammonia triggered the antioxidant response, it could not avoid oxidative damages [21,50]. Previous study also suggested that the increase of antioxidant enzyme activity in a short time was not sufficient to complete against stress-induced cellular damage along with the treatment duration [54].

Besides oxidative stress, the hepatopancreas and gills of H. cumingii showed histological change associated with ammonia exposure. We observed injury to the hepatopancreas during ammonia exposure, characterized by shrink of lumen, hemolytic infiltration, aggregation of lipofuscin, atrophy of digestive cells, and exfoliation of epithelial cells. Similar 
effects have been reported in Mytilus edulis (blue mussel) after cadmium [55] and mercuric chloride [56] challenge. Ammonia exposure also caused large interlamellar space, the exfoliation of cilia, and pyknosis of nucleus in the gills of $H$. cumingii. These have been observed in H. cumingii after bacterial challenge [57] and exposed to Microcystis aeruginosa under hypoxia [58]. The observed histological changes in our test indicated that ammonia caused severe damage to the internal physiology of the hepatopancreas and gills.

In addition, ammonia also enhances glutamine synthesis and partial amino acid metabolism. The conversion of excess ammonia to glutamine is the most common detoxification mechanism in aquatic animals, such as Paramisgurnus dabryanus [6] and Pelodiscus sinensis [59]. Glutamate is synthesized from ammonia and $\alpha$-ketoglutaric acid $(\alpha-K G)$ by the catalysis of GDH, which is then combined with ammonia to synthesize glutamine by GS [25,42]. Both glutamate and glutamine are nontoxic and easily transported to the circulatory system, which plays a key role in the detoxification of exogenous ammonia with high environmental ammonia and endogenous ammonia produced by amino acid catabolism in various tissues [35]. Results from the present study revealed that the GS activities in hepatopancreas and gills were significantly upregulated after ammonia stress. There was no significant difference of GS after $48 \mathrm{~h}$ in hepatopancreas, indicating that the organisms could not synthesize enough GS to detoxify at the later stages. Corresponding to the exposure time, the levels of GDH also increased significantly in hepatopancreas and gills. Under chronic ammonia exposure, both GDH and GS were elevated for the detoxification in Nile tilapia [60]. Besides, GDH was still significantly higher than that of the control after the GS decreased to normal level. This implied that the supply of glutamate was not perfectly matched with the demand under HEA, and the increased glutamate was not entirely used to synthesize glutamine for ammonia detoxification [61].

Moreover, ALT and AST can decompose glutamate into alanine and aspartate without releasing ammonia [6,24]. According to previous studies, there was another main ammonia detoxification strategy that partial catabolism of some amino acids led to the formation of alanine without releasing ammonia in fish [6]. In this study, the activities of ALT and AST were significantly upregulated in hepatopancreas, gills and hemolymph. It was hypothesized that the conversion of glutamate to alanine and aspartate is also one of the ammonia detoxification strategies in H. cumingii. Ammonia may be converted to glutamate by GDH first, and then to alanine and aspartate by ALT and AST.

\section{Conclusions}

In summary, we demonstrated the effects of ammonia exposure on the antioxidant responses and detoxification metabolism of $\mathrm{H}$. cumingii. The $96 \mathrm{~h} \mathrm{LC}_{50}$ and ammonia accumulation in the hemolymph showed that $H$. cumingii had strong ammonia tolerance. Ammonia exposure induced oxidative stress, but excessive ROS would accumulate with the extension of exposure time in the organism. The pro-oxidant effects of ammonia overwhelm the antioxidant defenses, leading to MDA accumulation eventually. Additionally, $H$. cumingii may be detoxified by transferring ammonia to glutamine, alanine and aspartate. In order to provide more ecotoxicological insights for healthy aquaculture and bioremediation, further research should focus on the detoxification and recovery in chronic ammonia exposure and water depuration in H. cumingii.

Author Contributions: Q.Z., K.F. and W.Y. conceived and designed the experiments; Q.Z., L.Z. and Y.B. performed the exposure experiment and determination of enzyme activity; Q.Z. and K.F. analyzed the experimental data and wrote the draft manuscript; K.F. and W.Y. revised the draft paper. All authors have read and agreed to the published version of the manuscript.

Funding: Earmarked Fund for China Agriculture Research System, Grant/Award Number: CARS-49; National Natural Science Foundation of China, Grant/Award Number: 31802268.

Ethics Statement: This study has been reviewed and approved by the Institutional Ethics Committee of Southwest University (IACUC Issue No.20190823-01; Approval date: 23 August 2019).

Informed Consent Statement: Not applicable. 
Data Availability Statement: The data that support the findings of this study are available from the corresponding author upon reasonable request.

Acknowledgments: The authors wish to express thanks to Xin Deng, Wenli Xu, Jiayi Li, and Zhenhui Xie for their participation and help during laboratory work, especially for their skillful experiment preparation and biochemical analysis. This work was supported by the China Agriculture Research System (Grant No. CARS-49) and Natural Science Foundation of China (Grant No. 31802268).

Conflicts of Interest: The authors declare no conflict of interest.

\section{References}

1. Gu, H.; Hu, M.; Wei, S.; Kong, H.; Huang, X.; Bao, Y.; Wang, Y. Combined effects of toxic Microcystis aeruginosa and hypoxia on the digestive enzyme activities of the triangle sail mussel Hyriopsis cumingii. Aquat. Toxicol. 2019, 212, 241-246. [CrossRef]

2. Wang, L.; Liu, P.; Sun, J.; Zhang, Y.; Zhou, Q.; Wu, Z.; He, F. Comparison and combination of selective grazing on natural seston by benthic bivalves (Hyriopsis cumingii) and pelagic fish (Hypophthalmichthys molitrix). Environ. Sci. Pollut. Res. 2018, 25, 33423-33431. [CrossRef]

3. Yan, L.-L.; Zhang, G.-F.; Liu, Q.-G.; Li, J.-L. Optimization of culturing the freshwater pearl mussels, Hyriopsis cumingii with filter feeding Chinese carps (bighead carp and silver carp) by orthogonal array design. Aquaculture 2009, 292, 60-66. [CrossRef]

4. Yang, Z.; Wu, H.; Li, Y. Toxic effect on tissues and differentially expressed genes in hepatopancreas identified by suppression subtractive hybridization of freshwater pearl mussel (Hyriopsis cumingii) following microcystin-LR challenge. Environ. Toxicol. 2010, 27, 393-403. [CrossRef] [PubMed]

5. Spencer, P.; Pollock, R.; Dubé, M. Effects of un-ionized ammonia on histological, endocrine, and whole organism endpoints in slimy sculpin (Cottus cognatus). Aquat. Toxicol. 2008, 90, 300-309. [CrossRef] [PubMed]

6. Zhang, Y.-L.; Zhang, H.-L.; Wang, L.-Y.; Gu, B.-Y.; Fan, Q. Changes of ammonia, urea contents and transaminase activity in the body during aerial exposure and ammonia loading in Chinese loach Paramisgurnus dabryanus. Fish Physiol. Biochem. 2016, 43, 631-640. [CrossRef]

7. Chen, S.; Yu, Y.; Gao, Y.; Yin, P.; Tian, L.-X.; Niu, J.; Liu, Y. Exposure to acute ammonia stress influences survival, immune response and antioxidant status of pacific white shrimp (Litopenaeus vannamei) pretreated with diverse levels of inositol. Fish Shellfish Immunol. 2019, 89, 248-256. [CrossRef] [PubMed]

8. Cheng, W.; Hsiao, I.-S.; Chen, J.-C. Effect of ammonia on the immune response of Taiwan abalone Haliotis diversicolor supertexta and its susceptibility to Vibrio parahaemolyticus. Fish Shellfish Immunol. 2004, 17, 193-202. [CrossRef]

9. Randall, D.; Tsui, T. Ammonia toxicity in fish. Mar. Pollut. Bull. 2002, 45, 17-23. [CrossRef]

10. Lemarié, G.; Dosdat, A.; Covès, D.; Dutto, G.; Gasset, E.; Ruyet, J.P.-L. Effect of chronic ammonia exposure on growth of European seabass (Dicentrarchus labrax) juveniles. Aquaculture 2004, 229, 479-491. [CrossRef]

11. Cheng, C.-H.; Yang, F.-F.; Ling, R.-Z.; Liao, S.-A.; Miao, Y.-T.; Ye, C.-X.; Wang, A.-L. Effects of ammonia exposure on apoptosis, oxidative stress and immune response in pufferfish (Takifugu obscurus). Aquat. Toxicol. 2015, 164, 61-71. [CrossRef]

12. Sun, H.; Lü, K.; Minter, E.J.; Chen, Y.; Yang, Z.; Montagnes, D.J. Combined effects of ammonia and microcystin on survival, growth, antioxidant responses, and lipid peroxidation of bighead carp Hypophthalmythys nobilis larvae. J. Hazard. Mater. 2012, 221, 213-219. [CrossRef]

13. Zhang, W.; Jiang, Q.; Yang, J.; Pan, D.; Liu, X.; Yang, Y. The effects of acute ammonia exposure on the immune response of juvenile freshwater prawn, Macrobrachium nipponense. J. Crustac. Biol. 2015, 35, 76-80. [CrossRef]

14. Benli, A.; Çağlan, K.; Köksal, G.; Özkul, A. Sublethal ammonia exposure of Nile tilapia (Oreochromis niloticus L.): Effects on gill, liver and kidney histology. Chemosphere 2008, 72, 1355-1358. [CrossRef]

15. Pinto, W.; Aragão, C.; Soares, F.; Dinis, M.T.; Conceição, L.E.C. Growth, stress response and free amino acid levels in Senegalese sole (Solea senegalensis Kaup 1858) chronically exposed to exogenous ammonia. Aquac. Res. 2007, 38, 1198-1204. [CrossRef]

16. Foss, A.; I Siikavuopio, S.; Sæther, B.-S.; Evensen, T.H. Effect of chronic ammonia exposure on growth in juvenile Atlantic cod. Aquaculture 2004, 237, 179-189. [CrossRef]

17. Pan, L.; Ren, J.; Liu, J. Responses of antioxidant systems and LPO level to benzo(a)pyrene and benzo(k)fluoranthene in the haemolymph of the scallop Chlamys ferrari. Environ. Pollut. 2006, 141, 443-451. [CrossRef]

18. Hu, M.; Wu, F.; Yuan, M.; Li, Q.; Gu, Y.; Wang, Y.; Liu, Q. Antioxidant responses of triangle sail mussel Hyriopsis cumingii exposed to harmful algae Microcystis aeruginosa and hypoxia. Chemosphere 2015, 139, 541-549. [CrossRef] [PubMed]

19. Lushchak, V.I. Environmentally induced oxidative stress in aquatic animals. Aquat. Toxicol. 2011, 101, 13-30. [CrossRef] [PubMed]

20. Liang, Z.; Liu, R.; Zhao, D.; Wang, L.; Sun, M.; Wang, M.; Song, L. Ammonia exposure induces oxidative stress, endoplasmic reticulum stress and apoptosis in hepatopancreas of pacific white shrimp (Litopenaeus vannamei). Fish Shellfish Immunol. 2016, 54, 523-528. [CrossRef]

21. Zhao, L.; Cui, C.; Liu, Q.; Sun, J.; He, K.; Adam, A.A.; Luo, J.; Li, Z.; Wang, Y.; Yang, S. Combined exposure to hypoxia and ammonia aggravated biological effects on glucose metabolism, oxidative stress, inflammation and apoptosis in largemouth bass (Micropterus salmoides). Aquat. Toxicol. 2020, 224, 105514. [CrossRef] [PubMed]

22. Hegazi, M.M.; Attia, Z.I.; Ashour, O.A. Oxidative stress and antioxidant enzymes in liver and white muscle of Nile tilapia juveniles in chronic ammonia exposure. Aquat. Toxicol. 2010, 99, 118-125. [CrossRef] [PubMed] 
23. Sıkdokur, E.; Belivermiş, M.; Sezer, N.; Pekmez, M.; Bulan Ömür, K.; Kılıç, Ö. Effects of microplastics and mercury on manila clam Ruditapes philippinarum: Feeding rate, immunomodulation, histopathology and oxidative stress. Environ. Pollut. 2020, $262,114247$. [CrossRef]

24. Zhang, Y.-L.; Wang, G.-Y.; Zhang, Z.-H.; Xie, Y.-Y.; Jin, H.; Dong, Z.-R. Partial Amino Acid Metabolism and Glutamine Synthesis as the Ammonia Defensive Strategies during Aerial Exposure in Chinese Loach Paramisgurnus dabryanus. Front. Physiol. 2019, 10, 14. [CrossRef] [PubMed]

25. Wicks, B.; Randall, D. The effect of sub-lethal ammonia exposure on fed and unfed rainbow trout: The role of glutamine in regulation of ammonia. Comp. Biochem. Physiol. Part A Mol. Integr. Physiol. 2002, 132, 275-285. [CrossRef]

26. Nakamura, K.; Cañete, J.; Vijuesca, D.; Guillén, N.; Sosa, C.; Mesquita-Joanes, F.; Sousa, R.; Ginés, E.; Sorribas, V. Sensitivity of Pseudunio auricularius to metals and ammonia: First evaluation. Hydrobiologia 2020, 1-16. [CrossRef]

27. Kleinhenz, L.S.; Humphrey, C.L.; Mooney, T.J.; Trenfield, M.A.; Van Dam, R.A.; Nugegoda, D.; Harford, A.J. Chronic ammonia toxicity to juveniles of 2 tropical Australian freshwater mussels (Velesunio spp.): Toxicity test optimization and implications for water quality guideline values. Environ. Toxicol. Chem. 2019, 38, 841-851. [CrossRef]

28. Beggel, S.; Hinzmann, M.; Machado, J.; Geist, J. Combined Impact of Acute Exposure to Ammonia and Temperature Stress on the Freshwater Mussel Unio pictorum. Water 2017, 9, 455. [CrossRef]

29. Zhang, T.; Yan, Z.; Zheng, X.; Wang, S.; Fan, J.; Liu, Z. Effects of acute ammonia toxicity on oxidative stress, DNA damage and apoptosis in digestive gland and gill of Asian clam (Corbicula fluminea). Fish Shellfish Immunol. 2020, 99, 514-525. [CrossRef]

30. Miao, J.; Barnhart, M.C.; Brunson, E.L.; Hardesty, D.K.; Ingersoll, C.G.; Wang, N. An evaluation of the influence of substrate on the response of juvenile freshwater mussels (fatmucket, Lampsilis siliquoidea) in acute water exposures to ammonia. Environ. Toxicol. Chem. 2010, 29, 2112-2116. [CrossRef]

31. Wang, N.; Consbrock, R.A.; Ingersoll, C.G.; Barnhart, M. Evaluation of influence of sediment on the sensitivity of a unionid mussel (Lampsilis siliquoidea) to ammonia in 28-day water exposures. Environ. Toxicol. Chem. 2011, 30, 2270-2276. [CrossRef]

32. Wang, H.; Xiao, X.-C.; Wang, H.; Li, Y.; Yu, Q.; Liang, X.M.; Feng, W.; Shao, J.; Rybicki, M.; Jungmann, D.; et al. Effects of high ammonia concentrations on three cyprinid fish: Acute and whole-ecosystem chronic tests. Sci. Total Environ. 2017, 598, 900-909. [CrossRef] [PubMed]

33. Goudreau, S.E.; Neves, R.J.; Sheehan, R.J. Effects of wastewater treatment plant effluents on freshwater mollusks in the upper Clinch River, Virginia, USA. Hydrobiologia 1993, 252, 211-230. [CrossRef]

34. Li, M.; Gong, S.; Li, Q.; Yuan, L.; Meng, F.; Wang, R. Ammonia toxicity induces glutamine accumulation, oxidative stress and immunosuppression in juvenile yellow catfish Pelteobagrus fulvidraco. Comp. Biochem. Physiol. Part C Toxicol. Pharmacol. 2016, 183-184, 1-6. [CrossRef] [PubMed]

35. Saha, N.; Dutta, S.; Bhattacharjee, A. Role of amino acid metabolism in an air-breathing catfish, Clarias batrachus in response to exposure to a high concentration of exogenous ammonia. Comp. Biochem. Physiol. Part B Biochem. Mol. Biol. 2002, 133, 235-250. [CrossRef]

36. Hong, M.; Chen, L.; Sun, X.; Gu, S.; Zhang, L.; Chen, Y. Metabolic and immune responses in Chinese mitten-handed crab (Eriocheir sinensis) juveniles exposed to elevated ambient ammonia. Comp. Biochem. Physiol. Part C Toxicol. Pharmacol. 2007, 145, 363-369. [CrossRef]

37. Farat, O.; Cogun, H.Y.; Yuzereroglu, T.A.; Gok, G.; Firat, O. A comparative study on the effects of a pesticide (cypermethrin) and two metals (copper, lead) to serum biochemistry of Nile tilapia, Oreochromis niloticus. Fish Physiol. Biochem. 2011, 37, 657-666. [CrossRef]

38. Kong, X.; Wang, S.; Jiang, H.; Nie, G.; Li, X. Responses of acid/alkaline phosphatase, lysozyme, and catalase activities and lipid peroxidation to mercury exposure during the embryonic development of goldfish Carassius auratus. Aquat. Toxicol. 2012, 120-121, 119-125. [CrossRef]

39. Qin, Q.; Qin, S.; Wang, L.; Lei, W. Immune responses and ultrastructural changes of hemocytes in freshwater crab Sinopotamon henanense exposed to elevated cadmium. Aquat. Toxicol. 2012, 106-107, 140-146. [CrossRef]

40. Peyghan, R.; Takamy, G.A. Histopathological, serum enzyme, cholesterol and urea changes in experimental acute toxicity of ammonia in common carp Cyprinus carpio and use of natural zeolite for prevention. Aquac. Int. 2002, 10, 317-325. [CrossRef]

41. Amacher, D.E. Serum Transaminase Elevations as Indicators of Hepatic Injury Following the Administration of Drugs. Regul. Toxicol. Pharmacol. 1998, 27, 119-130. [CrossRef]

42. Sinha, A.K.; Giblen, T.; AbdelGawad, H.; De Rop, M.; Asard, H.; Blust, R.; De Boeck, G. Regulation of amino acid metabolism as a defensive strategy in the brain of three freshwater teleosts in response to high environmental ammonia exposure. Aquat. Toxicol. 2013, 130-131, 86-96. [CrossRef]

43. Basha, P.S.; Rani, A.U. Cadmium-induced antioxidant defense mechanism in freshwater teleost Oreochromis mossambicus (Tilapia). Ecotoxicol. Environ. Saf. 2003, 56, 218-221. [CrossRef]

44. Jia, X.; Zhang, D.; Wang, F.; Dong, S. Immune responses of Litopenaeus vannamei to non-ionic ammonia stress: A comparative study on shrimps in freshwater and seawater conditions. Aquac. Res. 2015, 48, 177-188. [CrossRef]

45. Ighodaro, O.M.; Akinloye, O.A. First line defence antioxidants-superoxide dismutase (SOD), catalase (CAT) and glutathione peroxidase (GPX): Their fundamental role in the entire antioxidant defence grid. Alex. J. Med. 2018, 54, 287-293. [CrossRef]

46. Li, C.; Ni, D.; Song, L.; Zhao, J.; Zhang, H.; Li, L. Molecular cloning and characterization of a catalase gene from Zhikong scallop Chlamys farreri. Fish Shellfish Immunol. 2008, 24, 26-34. [CrossRef] [PubMed] 
47. Ni, D.; Song, L.; Gao, Q.; Wu, L.; Yu, Y.; Zhao, J.; Qiu, L.; Zhang, H.; Shi, F. The cDNA cloning and mRNA expression of cytoplasmic $\mathrm{Cu}$, Zn superoxide dismutase (SOD) gene in scallop Chlamys farreri. Fish Shellfish Immunol. 2007, 23, 1032-1042. [CrossRef]

48. De Felice, B.; Parolini, M. Effects of single and combined exposure to cocaine and benzoylecgonine on the oxidative status of Mytilus galloprovincialis. Environ. Toxicol. Pharmacol. 2020, 80, 103475. [CrossRef] [PubMed]

49. Verlecar, X.; Jena, K.; Chainy, G. Biochemical markers of oxidative stress in Perna viridis exposed to mercury and temperature. Chem. Interact. 2007, 167, 219-226. [CrossRef]

50. Liu, Y.; Li, L.; Zheng, L.; Fu, P.; Wang, Y.; Nguyen, H.; Shen, X.; Sui, Y. Antioxidant responses of triangle sail mussel Hyriopsis cumingii exposed to harmful algae Microcystis aeruginosa and high pH. Chemosphere 2020, 243, 125241. [CrossRef]

51. Gehringer, M.M. Microcystin-LR and okadaic acid-induced cellular effects: A dualistic response. FEBS Lett. 2003, 557, 1-8. [CrossRef]

52. Chetty, A.; Indira, K. Alterations in the tissue lipid profiles of Lamellidens marginalis under ambient ammonia stress. Bull. Environ. Contam. Toxicol. 1994, 53, 693-698. [CrossRef]

53. Aguirre-Martínez, G.V.; DelValls, A.T.; Martín-Díaz, M.L. Yes, caffeine, ibuprofen, carbamazepine, novobiocin and tamoxifen have an effect on Corbicula fluminea (Müller, 1774). Ecotoxicol. Environ. Saf. 2015, 120, 142-154. [CrossRef] [PubMed]

54. Wang, X.; Wang, L.; Yao, C.; Qiu, L.; Zhang, H.; Zhi, Z.; Song, L. Alternation of immune parameters and cellular energy allocation of Chlamys farreri under ammonia-N exposure and Vibrio anguillarum challenge. Fish Shellfish Immunol. 2012, 32, 741-749. [CrossRef] [PubMed]

55. Amachree, D.; Moody, A.J.; Handy, R.D. Comparison of intermittent and continuous exposures to cadmium in the blue mussel, Mytilus edulis: Accumulation and sub-lethal physiological effects. Ecotoxicol. Environ. Saf. 2013, 95, 19-26. [CrossRef] [PubMed]

56. Sheir, S.K.; Handy, R.D.; Galloway, T.S. Tissue injury and cellular immune responses to mercuric chloride exposure in the common mussel Mytilus edulis: Modulation by lipopolysaccharide. Ecotoxicol. Environ. Saf. 2010, 73, 1338-1344. [CrossRef] [PubMed]

57. Yang, Q.; Li, W.; Du, C.; Liu, Y.; Ma, S.; Yu, X.; Yao, W.; Wu, Z. Emerging pathogens caused disease and mortality in freshwater mussels, Hyriopsis cumingii, in China. Aquac. Res. 2020, 51, 5096-5105. [CrossRef]

58. Wu, F.; Kong, H.; Shang, Y.; Zhou, Z.; Gul, Y.; Liu, Q.; Hu, M. Histopathological alterations in triangle sail mussel (Hyriopsis cumingii) exposed to toxic cyanobacteria (Microcystis aeruginosa) under hypoxia. Aquaculture 2017, 467, 182-189. [CrossRef]

59. Ip, Y.K.; Lee, S.; Wong, W.; Chew, S. Mechanisms of and defense against acute ammonia toxicity in the aquatic Chinese soft-shelled turtle, Pelodiscus sinensis. Aquat. Toxicol. 2008, 86, 185-196. [CrossRef] [PubMed]

60. Hegazi, M.M.; Attia, Z.I.; Hegazi, M.A.; Hasanein, S.S. Metabolic consequences of chronic sublethal ammonia exposure at cellular and subcellular levels in Nile tilapia brain. Aquaculture 2010, 299, 149-156. [CrossRef]

61. Peh, W.; Chew, S.; Ching, B.; Loong, A.; Ip, Y.K. Roles of intestinal glutamate dehydrogenase and glutamine synthetase in environmental ammonia detoxification in the euryhaline four-eyed sleeper, Bostrychus sinensis. Aquat. Toxicol. 2010, 98, 91-98. [CrossRef] [PubMed] 